\title{
The METALLURGICAL ARTS AT THE PARIS EXHIBITION.
}

By F. LyNwOOd Garrison,

Delegate of the INSTITUTE.

[Continued from vol. cxxix, p. 374.]

COAL AND COKE.

PRODUCTION OF COAL AND COKE IN FRANCE IN 1887, COMPARED WITH I877.*

Coal-fields.

${ }_{2877 .}$

tonnes.

Northern coal-field, . . . . . . . . 6, 6,720,000

Loire coal-field, . . . . . . . . . 3,340,000

Gard coal-field, . . . . . . . . $1,660,000$

Burgundy and Nivernais coal-field, . . , 1,380,000.

Central coal-field, . . . . . . . . $1,020,000$

Aveyron and Tarn coal-field, . . . . . 975,000

Auvergne coal-field, . . . . . . . . 240,000

Herault coal-field, . . . . . . . . . . 238,000

South Vosges coal-field, . . . . . . . I86,000

Creuse and Corrèze coal-field, . . . . . 178,000

Western coal-field, . . . . . . . . 237,000

Western Alps coal-field, . . . . . . . 132,000

Total for coal and anthracite, . . 16,305,000

Proven cland Alps brown coal-fields, . . 470,000

Sundry brown coal-fields, . . . . . . 30,000

Total for brown coal,

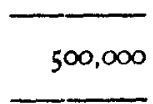

Sum total, . . . . . . I I6,805,000

A.R.-The French torne is 1,000 kilograms.
1887.

tonnes.

$11,317,000$

$2,989,000$

$1,831,000$

$\mathrm{I}, 497,000$

994,000

$\mathrm{I}, 076,000$

291,000

208,000

I 86,000

I 53,000

136,000

I 32, 000

$20,810, \infty 00$

457,000

21,000

478,000

$21,288,000$

* Journal of Iron ani Steel Inst., No. 2, I889, p. I1. 


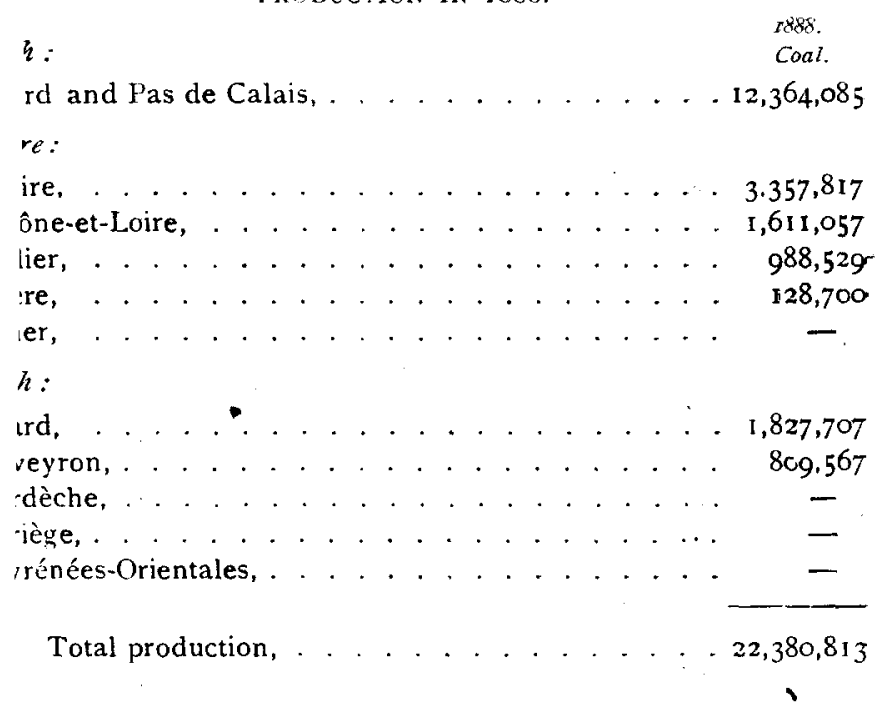

: output of the French collieries for the first half of the 389 is stated to be as follows : $\dagger$

1 and anthracite, I I,696,020 tons, an increase of 835,085 ver the first half the year I888. Lignite, 2 Io,954 tons, ease of 5,842 over the first half of the year 1888 .

vill be observed that the output of coal in France has sed about 40 per cent. since 1887 , and that this se has been nearly altogether in the Northern coal-

e coal consumption of France having been 31,191,000 or 1887 (instead of $24,144,490$ tons for 1877 ), the foreign ts must have been $10.565,000$ tons (including 4,046,000 of British coals), instead of $7,882,000$ tons (including xoo tons of British coals), for 1877 .

will be observed from the above figures that the coal mption in France in 1887 was more than a third ar than the total output of the French collieries. The tations for that year amounted to $10,565,000$ tons, of 1 about half was British and the balance, I suppose,

Tron Age, September 5, 1888, p. 371 .

Sulletin ilu Comitć des Forges, No. 249, pp. 55-57. 
Belgian and German coal. I regret I have no figures of the importations for the later years, but I understand the amount has been steadily increasing each year.

Owing to the rather distorted condition of many of the French coal-fields much of the output is broken up into such a fine condition that it cannot be used for ordinary purposes unless mixed with much coarser coal or combined with pitch and compressed into blocks. The manufacture of these blocks or briquettes, as they are called, has become quite an extensive industry in France. A number of the French coal companies had extensive displays of machinery for this purpose at the exhibition. Without going into detail, it will suffice to say that the industry is a rapidly developing one on the continent of Europe, and the indications are, that before long some similar system will be adopted to utilize the enormous waste heaps in the anthracite regions of our country.

The great Northern coal-field is reptesented in the Exhibition by the Anzin, Aniche, Escarpelle, Douchy, and Vicoigne collieries, situated in the department of the North, and by the Lens and Douvrin, Courrières, Bethune, Noeux, Bruay, Dourges, Fléchinelles, Lievin, Meurchin, and Drocourt collieries, situated in the Pas de Calais.

The Loirc coal-ficld is represented by the four more important mining companies, viz: the Montrambert and Beraudière Company, the Loire Company, the St. Etienne Company, and the Roche-la-Moliére and Firminy Company. The coalfield, as a whole, is illustrated by an interesting plan in relief.

The several collieries of the Gard coal-field exhibit a very fine geological plan in relief of the coal-field as a whole, and each of them, viz: the Grand Combe, Bessèges, Portes and Senechas, Rochebelle, Trelys, Cessous and Comberedonde, Salles and Montalet has also its individual exhibits.

The Burgundy and Nivcrnais coal-ficld is represented by. the beautiful exhibit of the Blanzy collieries, and by the geological maps of the Decize colliery (owned by Messrs. Schneider \& Co.).

The Cintral coal-field has sent plans in relief of the Saint 
Eloi and of the Bezenet collieries, as well as models of the Commentry colliery, prepared so as to illustrate the delta theory of coal-field formations put forward by M. Fayol.

The Aveyron collieries are represented in the metallurgical gallery by the plans and drawings of the Aubin mines; and the Tarn collieries in the "Palais des Machines" by the exhibits of the Carmaux Mining Company, and of the Tarn Mining Society.

The Ronchamp colliery, in the South Vosges, exhibits its plans and products.

The Graissessac mines (Herault) are represented in the “Metallurgical Gallery," as well as the Bouches du Rhone lignite collieries, which exhibit the brown coals of Greasque and the Rocher bleu.*

Coke.-Most of the coke produced in France is made in improved ovens such as the Coppée, Smet, Carves, etc. The vertical $A$ ppolt ovens are now but little used; thex are only to be seen at Blanzy, Creusot and Bezenet. The almost obsolete beehive ovens are used at only one or two collieries, the coke made in them being mostly used for foundry purposes. Messrs. Seybel \& Bernard displayed at the Exhibition a number of drawings of improved coke ovens, especially intended for coking of poor coals.

The application of coke ovens to the production of tar and ammoniacal salts does not seem to have met with much success in France, for the reason, it is said, that the quality of the French coals is not so well suited to the production of by-products as the English and German coals.

Iron Ore.-The consumption of iron ore in France in 1877 and 1887 is classified as follows :

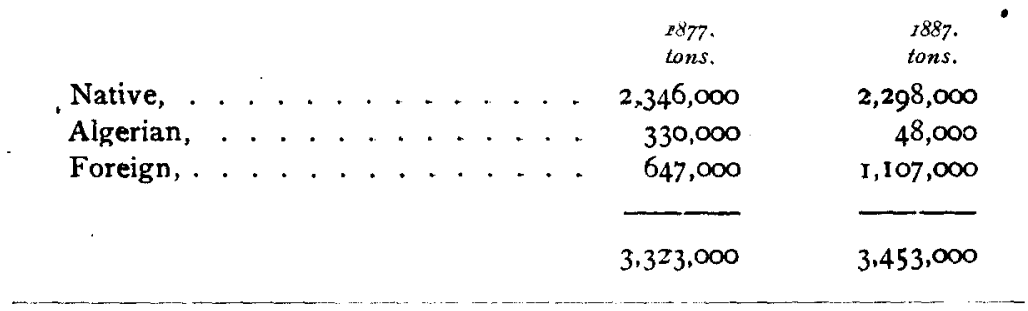

* Journ. Iron and Steel Inst., No. 2, 1889, pp. I I-12. 
It would appear from the above that the otlput uf iron ore in France was retrograding; this, however, is only truc as regards the scattered deposits of ore in the eastern and central districts, which are unable to compete in cheaper ores on the eastern portion and of the north of Spain. It is. therefore, possible that the active development going on in Meurthe and Moselle district will, in a few years, largely increase the total output of the country.

The chief cause of the large decrease is the consumption of Algerian ore is due to the diminished yield of large mines near Bona. The largest supplies of imported ore are drawn mostly from Bilbao, and in a somewhat lesser degree from Luxembourg.

The best spathic ores in France come from a few districts in the Eastern Pyrennes and Savoy. The former are used by Messrs. Holtzer \& Co. in their charcoal blast furnaces at Ria, the pig from which is mostly used for making crucible steel. The oölitic ores are similar in composition to those in Northamptonshire and Lincolnshire in England. One of the best representative series is that of Micheville, near Longwy, where three beds are worked of the following composition :

\begin{tabular}{|c|c|c|c|c|c|}
\hline & Silica. & fluminium. & Lime. & Iron. & Phosphorus. \\
\hline $81 / 2$ & $13^{\circ}$ & 6.70 & 18.80 & $27^{\circ} 02$ & I'16 \\
\hline hick & 3 & 7.07 & $7 \cdot 24$ & $39 \cdot 80$ & $I \cdot 46$ \\
\hline ck), & 15. & 6.87 & 477 & $40 \cdot 80$ & $I \cdot 45$ \\
\hline
\end{tabular}

The middle bed is found to give the best results in the furnace. About I00,000 tons of these ores are mined annually and smelted with additions of Luxembourg ores.

A remarkable series of deposits of magnetic iron ores, almost totally different from any other in Western Europe, have been recently developed near Cherbourg. These deposits occur in nearly vertical beds and belts from ten to forty-five feet in thickness in the quartzite flanking the coast cliffs, the outcrops of the beds nearest the shore alone being visible at lowest spring tides. The ore runs from fiftyfive to sixty per cent. iron, eight to fourteen per cent. silica, and 0.25 to one per cent. phosphoric acid. 
THE PIG IRON MANUFACTURE.

According to official statistics, the production in $\mathbf{I} 882$, I 887 and I 888 was as follows:

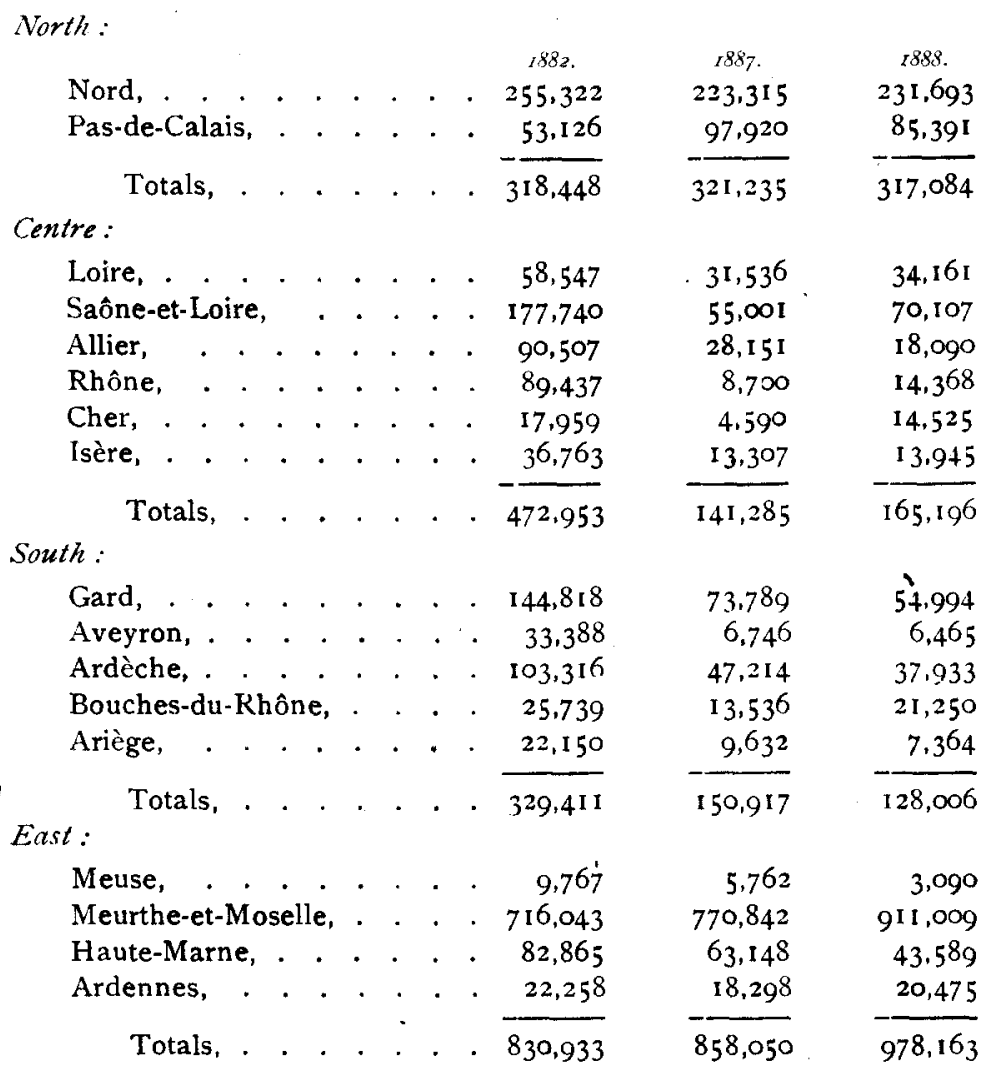

The total product of the three years was $2,039,000$ metric tons in $1882,1,306,930$ tons in 1887 and $\mathrm{I}, 688,976$ tons in $\mathrm{I} 888$; $60,23 \mathrm{I}, 20,886$ and 22,792 tons thereof being pig made with charcoal or a mixture of charcoal and coke as fuel. Of the totals named, $44 \mathrm{I}, 318$ tons in $1882,355,892$ tons in 1887 and 382,046 tons in 1888 were foundry iron, the balance being mill iron and pig used for conversion into steel. A glance at the figures compiled for the different districts shows how high, relatively, is the position of the east, that section which adjoins and participates in the famous minette ore 
fields of Luxembourg. Its percentage rose from 40.7 in I 882 to $65^{\circ} 6$ in $\mathrm{I} 887$ and fifty-eight in I 888 . $^{*}$

The production for the first half of 1889 is stated to have been as follows:

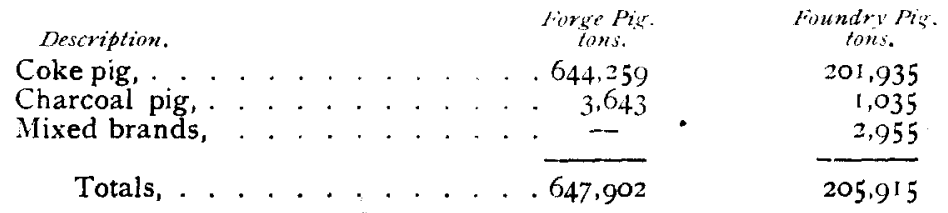

The total production thus amounted to 853,817 metric tons, against 821,824 tons in the first half of 1888 , the increase being $31,993 .+$

The following table shows the total production in the various departments for the year $1889 \neq$ :

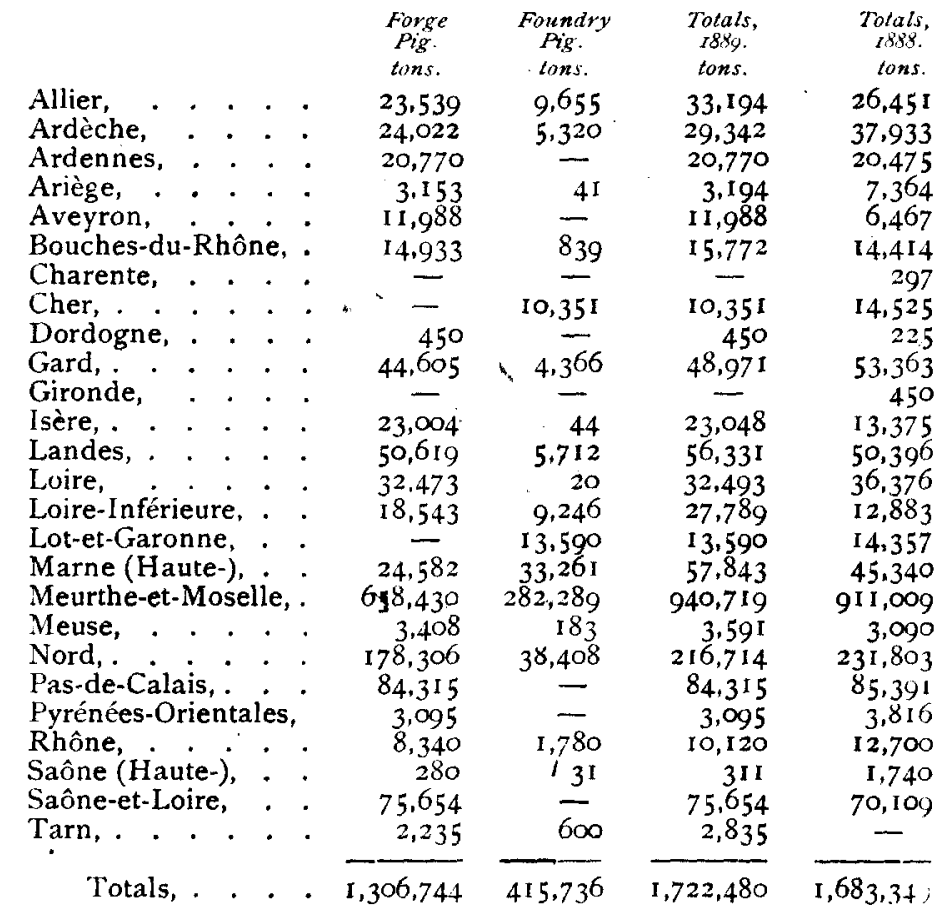

* Iron Age, September 5, 1889, p. 37 I.

$\dagger$ Bulletin du Comite des Forges, No. 249, pp. 58-62.

$+\operatorname{Iron}$ (Eng.), March 7, I89o, p. 216. 
The production of charcoal pig iron has continuously decreased. In 1887 , there were only a few charcoal furnaces in blast, some of them in Southwestern France, making special gray pig for ordnance purposes; two in the FrancheComté district; one in the Alps (Isère), and one in the Western Pyrenees.

The Brignoud blast furnace (Isère) is smelting alpine spathic ores, and produces the excellent charcoal pigs used in the Bonpertuis Steel Works for the production of steel by charcoal hearth refining.

The Ria blast furnace (Western Pyrenees), belonging to Messrs. J. Holtzer \& Co., is producing, with the manganiferous brown hematites and the spathic ores of the country, gray and white manganiferous pigs, used in the Unieux Steel Works for making their celebrated products.

For a number of years it was a peculiar practice with some of the French blast furnace managers to use a mixture of coke and charcoal; the practice, however, appears to be dying out, and at the present time is only in use in a few furnaces in Eastern France.

The following statement shows the changes in blast furnace plants which have taken place during the decade from I877 to 1887 :

\section{IRON FURNACES IN BLAST.*}

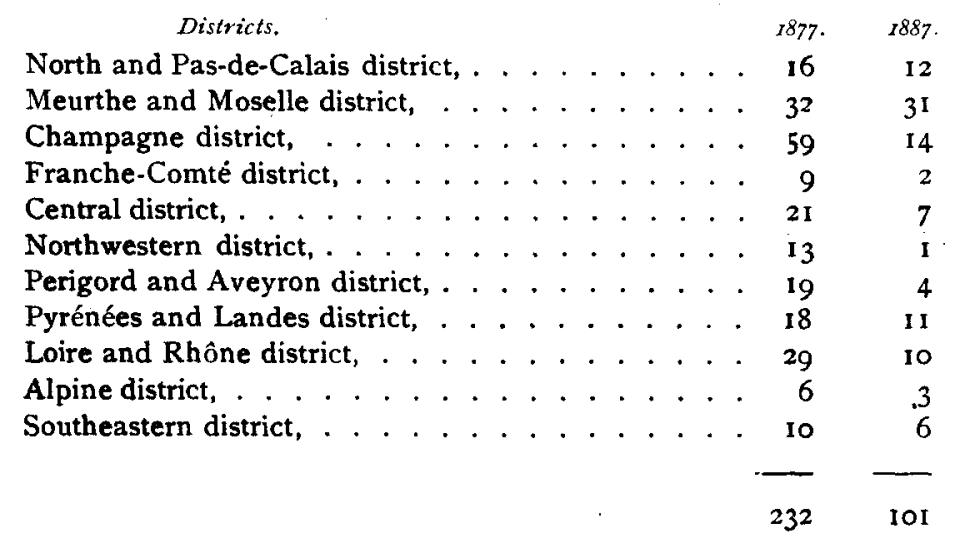

* Journ. Iron and Steel Inst., No. 2, 1889, pp. 14-15. 
The total number of blast furnaces has decreased more than one-half, but the production of pig iron has nevertheless increased. From about 6,500 tons, the mean annual output per furnace has increased to 15,500 tons, and, if the details were considered, it would be found that the progress in this respect has occurred in the two first districts, and, above all, in the Meurthe and Moselle district, which, with less than one-third part of the total number of the French furnaces, has produced more than one-half of the total annual production of pig iron.

Some of the iron works in the Loire region are using, for the production of superior iron and steel with ordinary pig, a special refining process (Rollet's process). It consists in the melting of the pig with an extra-basic slag, obtained by means of fluorspar and limestone. This melting is effected in a basic-lined or water-jacketed cupola furnace, blown by hot blast. The pig iron is thus purified by the removal of the greater part of its sulphur and of a certain portion of its phosphorus. The refined metal obtained is sometimes cheaper than the pure pig made with manganiferous foreign ores. The Rollet process is not specially exhibited, but its products can be seen among the exhibits. of the Holtzer and Firminy Campanies.

PRODUCTION OF ROLLED IRON IN FRANCE IN 1882, I887 AND I888.

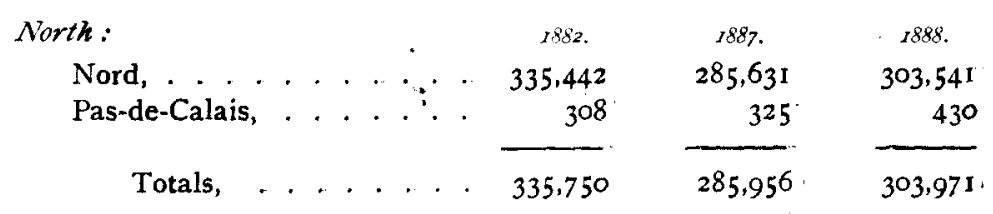

Centre:

\begin{tabular}{|c|c|c|c|c|}
\hline Loire, & . . & 84,280 & 37,361 & 37,115 \\
\hline Sâône-et-Loire, & . & 64,949 & 68,126 & 71,564 \\
\hline Allier, . . . & 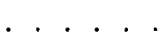 & 38.378 & 29,360 & $3 I, 631$ \\
\hline Cher, & . & 570 & 560 & 627 \\
\hline Isère, & $\cdots \cdots$ & 14,833 & 5,155 & 4,009: \\
\hline lièvre, . . . & . . . . & 20,373 & 5,049 & 6,672 \\
\hline tals, & $x^{\prime}$ & 223,383 & 145,611 & $151,614$. \\
\hline
\end{tabular}


South :

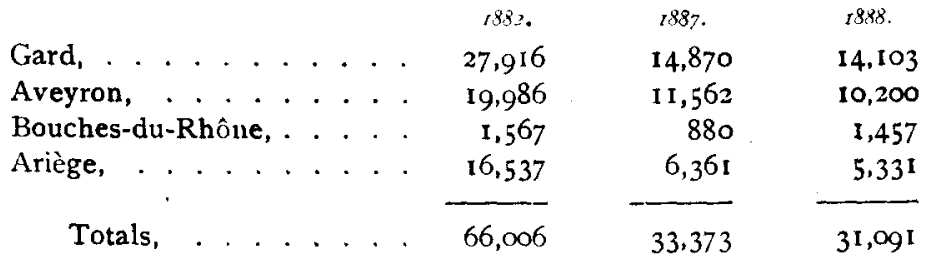

East :

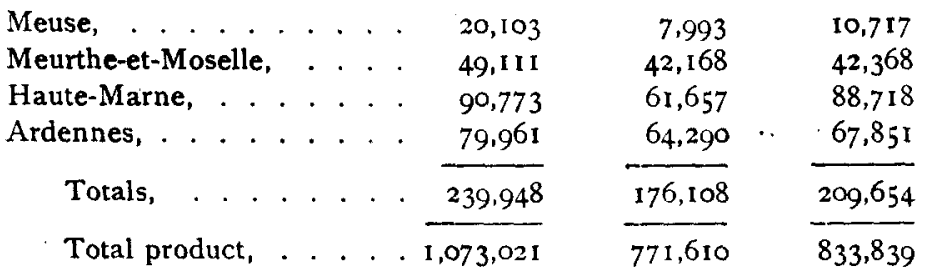

The total production of wrought iron, in I882, was 1,073,02I metric tons, which declined to $77 \mathrm{I}, 6 \mathrm{IO}$ tons in 1887 , rising again to 833,839 tons in $\mathbf{I} 888$.

Many changes have taken place in this industry in France since I 878 . Prof. Jordan gives the following figures in relation to it and to the mantufacture of steel in open fires and puddling furnaces :*

\begin{tabular}{|c|c|c|c|}
\hline & & 1877 & 1887. \\
\hline Number of puddling furna & - . & 995 & 637 \\
\hline of puddling furnaces (steel), . & . & 51 & 35 \\
\hline Number of open-fires (iron), & .. & 243 & 3 \\
\hline of open-fire & . . & tans. & \\
\hline $\begin{array}{l}\text { Production of puddled iron, } \\
\text { Production of charcoal refined iron, } \\
\text { Production of puddled and charcoa }\end{array}$ & $\therefore$ & $\begin{array}{r}821,006 \\
63,487\end{array}$ & $\begin{array}{r}617,997 \\
16,864\end{array}$ \\
\hline
\end{tabular}

The practice of puddling iron is gradually decreasing, owing to the increased use of soft steel for structural purposes.

The following are details of the production of "finished iron" in France during $1889 . \dagger$

* "Notes on the Iron and Steel Manufacture in France, in $1887 . "$ Journ Iron and Steel Inst., No. 2, 1889, p. 21 .

$\dagger \operatorname{Irun}$ (Eng.) March 7, 189o, p. 216. 
FINISHED IROX.

\begin{tabular}{|c|c|c|c|c|c|c|}
\hline & & $\begin{array}{l}\text { Rails. } \\
\text { tons. }\end{array}$ & $\begin{array}{l}\text { Merchant } \\
\text { Iron. } \\
\text { tons. }\end{array}$ & $\begin{array}{l}\text { Mates. } \\
\text { lons. }\end{array}$ & $\begin{array}{l}\text { sing. } \\
\text { luns. }\end{array}$ & $\begin{array}{l}\text { W. } \\
\text { tons. }\end{array}$ \\
\hline sne & . & - & - & $34 \mathrm{I}$ & $34 I$ & 3714 \\
\hline 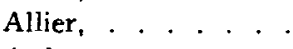 & & 197 & 19,368 & 7,888 & 27,453 & 631 \\
\hline dennes, & & - & 54.496 & 13,873 & 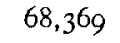 & 7,851 \\
\hline iège, . . . . & . & - & 5,664 & 一 & 5,664 & 5,330 \\
\hline abe, & . . & - & $5,09 !$ & - & 5,09 & 5,476 \\
\hline yron, ..... & . . & - & 14,407 & - & 14,407 & 10.207 \\
\hline s-du-Rhône, . & . & - & 1,395 & - & 1,39 & 1,457 \\
\hline te, . . . . . & . . & - & - & - & - & 223 \\
\hline$\ldots \ldots$ & . . & - & - & - & - & 627 \\
\hline ôte-d'Or, . . . • & . . & - & 6,324 & 556 & $6,88 c$ & 7,870 \\
\hline $\mathrm{u}$-Nord, . . & . . & - & 3.550 & - & 3 & 3.945 \\
\hline$e, \ldots .$. & . . & - & & -- & & 2,415 \\
\hline 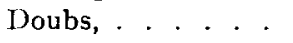 & . & - & 2,1 & 2,584 & 4,771 & 14.533 \\
\hline 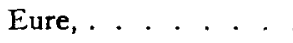 & . . & -- & 5,1 & - & & 2,900 \\
\hline ra & . . & I $2 I$ & 13,2 & - & 13. & 14,089 \\
\hline (Haute-), . & . & - & - 1 & - & & 1,288 \\
\hline . . . & .1 & - & 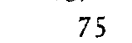 & - & & 18 \\
\hline ine, & . & - & 0 & - & & 13 \\
\hline$\ldots$ & . . & - & 2,682 & - & 2,682 & 4,006 \\
\hline . . . . & & - & I0, 579 & 5,097 & I 5,676 & 12,358 \\
\hline . . . & . & - & $6,69 \mathrm{I}$ & - & $6,69 \mathrm{I}$ & 5,053 \\
\hline her,. & . . & - & 3 & - & 31 & \\
\hline & . & - & $28, \infty 05$ & 8,7 & 36 & 6,523 \\
\hline eure, . & & - & 10.334 & $\mathrm{I}, 2$ & 1,5 & 1,196 \\
\hline ane, . & $\cdot$ & - & & - & & 14 \\
\hline te-), & . & - & 55,1 & 4,2 & 9,366 & 65,77 \\
\hline t-Moselle, . & . & 1 & 33. & 7,2 & 35 & 42,368 \\
\hline$\ldots \ldots$ & . & - & & - & & 7.022 \\
\hline . . . & . & 231 & 6,0 & & 10 & 672 \\
\hline . . . . . & . & - & 9,9 &, 563 & 0,494 & 07,555 \\
\hline .... & . & :- & 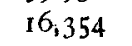 & 1,600 & 17,954 & 13,027 \\
\hline . . & . . & - & 250 & - & 250 & 200 \\
\hline is, . . . & . . & - & 521 & - & 521 & 43 \\
\hline entales, & .. & - & & - & & 182 \\
\hline Belfort), & . & - & 160 & - & 10 & 170 \\
\hline . . . . & . & - & 00 & - & 0 & - \\
\hline te-), . & . & - & 11 & 143 & 34 & 1,075 \\
\hline pire, . & $\therefore$ & - & 57.915 & 1,626 & $69,54 \mathrm{I}$ & $71 ; 049$ \\
\hline$\cdot \cdots$ & . & - & 33 & - & 3 & 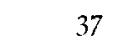 \\
\hline . . . & . . & - & I & - & & \\
\hline ute-), . & . & - & I,oro & 854 & $I, 864$ & 1,881 \\
\hline & . & - & $34,26 \mathrm{I}$ & - & $34,26 \mathrm{I}$ & 53 \\
\hline Seine-Inférieure, & & - & 250 & - & 250 & \\
\hline
\end{tabular}


FINISHED IRON.-Continued.

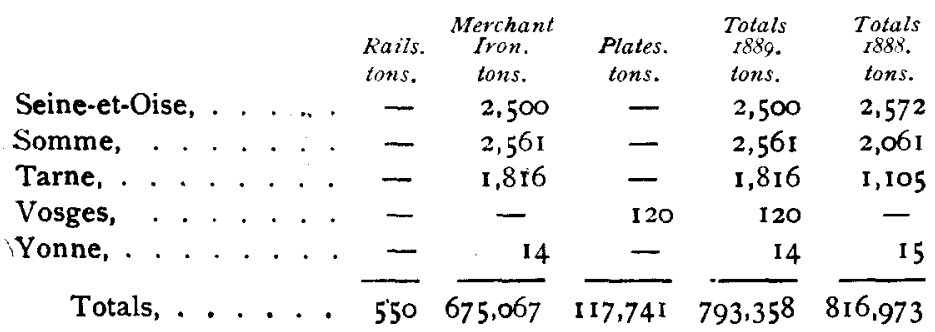

PRODUCTION OF STEEL IN FRANCE IN I882, I887 AND 1888.

\begin{tabular}{|c|c|c|c|c|c|c|c|c|c|}
\hline $\begin{array}{l}\text { North: } \\
\text { Nord, . . . } \\
\text { Pas-de-Calias, }\end{array}$ & $\begin{array}{l}. \\
.\end{array}$ & . & & & . & $\begin{array}{l}1882 . \\
61,853 \\
-\end{array}$ & & $\begin{array}{l}2887 . \\
87,664 \\
61,462\end{array}$ & $\begin{array}{c}1888 . \\
95,212 \\
50,985\end{array}$ \\
\hline Centre: Totals, & $\cdot \cdot$ & $\cdot$ & & . & . & 61,853 & & 149,126 & 146,197 \\
\hline Loire, . : & . . & 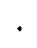 & & & . & 132,529 & & 54,536 & 67,613 \\
\hline Saône-et-Loire, & . . & . & . & . & . & 101,320 & & 45,519 & 48,746 \\
\hline Allier, ... . . & . . & . & . & . & . & 23,301 & & 11,527 & 10,360 \\
\hline Isère, ... . . & . . & . & . & 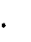 & . & 8,739 & - & 4,321 & 3,859 \\
\hline Nièvre, ... & . . & . & & & . & $5.73 \mathrm{I}$ & & 9.897 & 9,070 \\
\hline East: Totals, &.. & . & & & . & 271,620 & & 125,800 & 139,653 \\
\hline Meuse, . . & . . & . & . & & "* & 51 & & $5,55^{8}$ & 6,155 \\
\hline Meurthe-et-Mos & selle, & & & & & 1,616 & & 41,265 & 37,814 \\
\hline Haute-Marne, & . . & 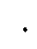 & & & · & - & & 9,160 & $16: 327$ \\
\hline Ardennes, & $\cdot \cdot$ & - & & & · & 171 & & 18,218 & 21,096 \\
\hline South: Totals, & . & . & & & . & 1,838 & & 74.201 & 81,392 \\
\hline Gard, . . . & . . & - & & & 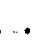 & 83,579 & & 40,534 & 34,722 \\
\hline Aveyron, . & . & . & & & . & 25,803 & & - & - \\
\hline Ariège, $\ldots$ & . & · & & & - & 6,223 & & 4,496 & 2,087 \\
\hline Totals, & & & & & & 115,605 & & 44,030 & 36,809 \\
\hline Total produ & uct, & 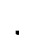 & & & . & 458.238 & & 493,294 & 525,646 \\
\hline
\end{tabular}

PRODUCTION OF STEEL RAILS IN FRANCE.

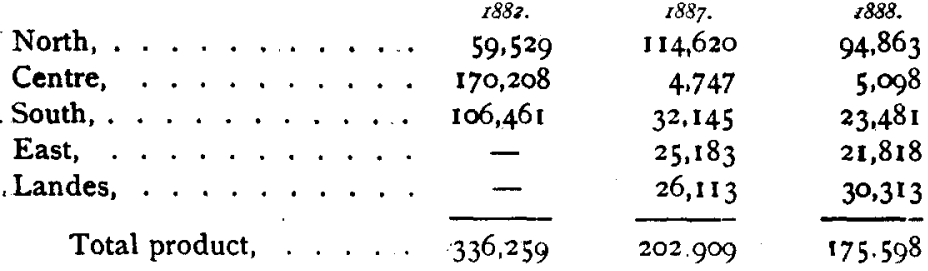


PRODUCTION OF STEEL FOR THE FIRST HALF OF 1889 , COMPARED WITH THAT OF THE FIRST HALF OF 1888.

$$
\text { Description. }
$$

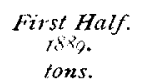

Rails, Bessemer, . . . . . . 75,412

Rails, open hearth, . . . . . 3.549

Total, . . . . . $\quad \overline{75.961}$

Merchant steel, Bessemer, . . . 52,529

Merchant steel, open hearth, . . 54,794

Merchant steel, puddled, : . . 12,177

Merchant steel, cement, . . . . 776

Merchant steel, crucible, . . . 5,493

Total, . . . . . . . 125,769

Plates, Bessemer, . . . . . . 15,192

Plates, open hearth, . . . . . 21,820

Plates, miscellaneous,

Total, . . . . . $\overline{41,358}$

Total steel, . . . . . . 246,088
First Half.
tidy.
cons.

83.538

$\frac{3,537}{87,075}$

46,905

$4 \pi, 796$

$13,06 \mathrm{r}$

686

4,304

106,752

$17,925-2,733$

$22,655-835$

5,217 -

$45,797-4,439$

$239,624+6,464$

TOTAL PRODUCTION OF STEEL IN THE DIFFERENT DEPARTMENTS OF FRANCE DURING I889.*

Aisne, . . . . . - $\quad-\quad 702 \quad 702 \quad 644$

Allier,....... $\quad 70 \quad 9,926 \quad 4,102 \quad 14,198 \quad 10,360$

Ardennes, . . . . $\quad-\quad \begin{array}{lllll}\text { A } & \text { 8,691 } & 14,696 & 23,387 & \mathbf{2 2 , 0 3} 8\end{array}$

Ariège, . . . . . - 4,566 - $4.566 \quad 2,931$

Aube, . . . . - 3.048 - $3.048 \quad 2,950$

Charente, . . . . - $-168 \quad-\quad 168-$

Côte-d'Or, ..... $\quad 60 \quad 2,587 \quad 127 \quad 2,774 \quad 604$

Côtes-du-Nord, . . + $+18-18 \quad 15$

Doubs, . . . . . $\quad \begin{array}{llllll} & - & 7,331 & 1,435 & 8,766 & 1,748\end{array}$

Gard, . . . . . $18,430 \quad 13,817 \quad-\quad 32,247 \quad 34,843$

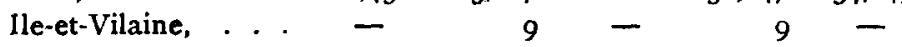

Isère, ...... - $\quad$ - $5.367 \quad-\quad 5,367 \quad 4.751$

Jura, ...... $\quad-\quad \begin{array}{lllll}12,139 & 3,360 & 15,499 & 5,496\end{array}$

Landes, . . . . 22,871 $3,920 \quad-26,791 \quad 34,378$

$\begin{array}{llllll}\text { Loire, . . . . . . . } & 2,093 & 50,457 & 12,178 & 64,728 & 68,490\end{array}$

$\begin{array}{llllll}\text { Loire-Inférieure, . . } & - & 4,852 & 6,578 & 11,430 & 7,775\end{array}$

$\begin{array}{llllll}\text { Marne (Haute-), . . } & - & 13,911 & 721 & 14,632 & 14,637\end{array}$

$\begin{array}{llllll}\text { Meurthe-et-Moselle, . } & 28,132 & \text { I } 3,829 & 2,242 & 44,703 & 37,873\end{array}$

* Iron (Eng.), March 7, I890, p. 216. 
TOTAL PRODUCTION OF STEEL IN THE DIFEERENT DEPARTMENTS OF FRANCE DURINe 1889.-Continued.

\begin{tabular}{|c|c|c|c|c|c|}
\hline 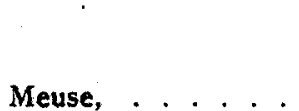 & $\begin{array}{c}\text { Rails. } \\
\text { tons. } \\
-\end{array}$ & $\begin{array}{l}\text { Bars. } \\
\text { tons. } \\
8,819\end{array}$ & $\begin{array}{c}\text { Plates. } \\
\text { cons. } \\
-\end{array}$ & $\begin{array}{c}\text { Totals, } \\
\text { r889, } \\
\text { tons. } \\
8,819\end{array}$ & $\begin{array}{c}\text { Totals, } \\
\text { r888. } \\
\text { tons. } \\
7,150\end{array}$ \\
\hline Morbihan, . . . & - & - & II,950 & $\begin{array}{r}0,009 \\
11,950\end{array}$ & 10,000 \\
\hline Nièvre, . . . ... & 178 & 8,443 & .767 & 9,388 & 11,112 \\
\hline Nord, . . & 25,202 & 33.919 & 8,109 & 67,230 & 84,988 \\
\hline Oise, . . . . & - & 16,825 & 1,108 & 17,993 & 13,053 \\
\hline Pas-de-Calais, . . . & 42,717 & 7,804 & - & 50,521 & 51,002 \\
\hline Rhin-Haut (Belfort), & - & 3,224 & - & - & 2,830 \\
\hline Rhône, . . . . & - & 275 & - & 275 & 364 \\
\hline Saône (Haute-), . . & - & 一 & 30 & 30 & - \\
\hline Saône-et-Loire, . . & 5,594 & 24.030 & 18,338 & 47,962 & 48,911 \\
\hline Savoie, & - & 80 & - & 80 & 81 \\
\hline Seine, . . . . & - & 2,942 & - & $2,94:$ & 2,176 \\
\hline Seine-Inférieure, . & - & 4 & - & 4 & - \\
\hline Tarn, . . . . . & - & $\mathrm{I}, 940$ & - & 1,940 & 1,934 \\
\hline $\begin{array}{l}\text { Vosges, } \\
\text { Works not enumer- }\end{array}$ & - & - & $1,680^{\circ}$ & 1,680 & 1,660 \\
\hline ated, . . . . . & - & 32,000 & $\because$ & 32,000 & 32,500 \\
\hline Totals, . . . . & 347 & 951 & .723 & 9,021 & 7,294 \\
\hline
\end{tabular}

MANUFACTURE OF STEEL IN CONVERTERS.

Prof. Jordan states that, according to official statistics, there were twenty-four Bessemer converters at work in France during the year 1877 , but no data is given of their output. In 1887 , twenty-eight were in operation. The output of acid Bessemer and of basic steel is not indicated for that year, but Prof. Jordan estimates the production of basic steel at 143,000 tons. Prof. Jordan remarks that "the producing power of basic steel in the French steel works is, however, much greater than would be supposed from these figures, as well as of acid Bessemer steel. Indeed, although the official statistics indicate that some twenty-eight converters were at work in 1887 , this only represents about twothirds of the actually existing converters, which will number from forty-two to forty-four. Some Bessemer steel works have been entirely idle in 1887 , such as those of Terrenoire, Givors, Saint Nazaire, Pagny on the Meuse, while some others worked with only a part of their plant.

The Bessemer steel manufacture was first.introduced in 
France in Messrs. Jackson \& Co.s works at Saint-seurin-onl'Isle, near Bordeatx, and afterwards in Messrs. Petin, Gaurlet \& Co.'s works at Assailly (Loire). It was afterwards developed in various districts. especially in the Centre, at the Imphy and Montluçon Works; in the Loire district, at the Terrenoire, Creusot, Saint Etienne, and Givors Works: and in the Gard district, at the Besseges Iron Works. The pig iron used by these works was made with mixtures of local ores and ores imported from Algiers and Spain, these last being somewhat dear, owing to the sea and railway freights. Hence, the new steel works, established during the last ten or twelve years, have been located in the closer neighborhood of seaports, such as the Denain Steel Works (the first built), the Isbergues, Saint Nazaire, Boucau, and Beancaire Steel Works, the first four being intended for using Spanish and the last for Algerian ores.

The Isbergues Steel Works (Pas-de-Calais), belonging to the Acieries of France Company, are provided with two eight-ton American type converters and are supplied with pig iron from two large blast furnaces. They announce their annual steel-producing power as 100,000 tons. These works exhibit their raw materials and their steels, classed in five categories, according to their hardness and mechan. ical properties. They have hitherto produced all kinds of steel rails, steel girders, blooms and billets.

The Adour forges or Boucau Steel Works, near Bayonne, belonging to the "Acieries de la Marine et des Chemins de Fer" Company, having two converters, also exhibit a ground. plan of their works, their raw materials and their products, accompanied by interesting analyses. They produce cast steel, distributed into fifteen numbers or classes, from the hardest to the softest. These works have also SiemensMartin furnaces. They were established in 1883 , specially for making steel rails, but since that time they have been obliged to look for other markets.

It is the same with the Denain Steel Works, which exhibit only their products in the special annex of the northern forges, and which possess also open-hearth furnaces.

Whote No. Vol. CXXIX.-(Third SFeries, Vol, xcix.) 
The manufacture of basic Bessemer steel, or so-called Thomas-Gilchrist steel, is effected in the four following works :

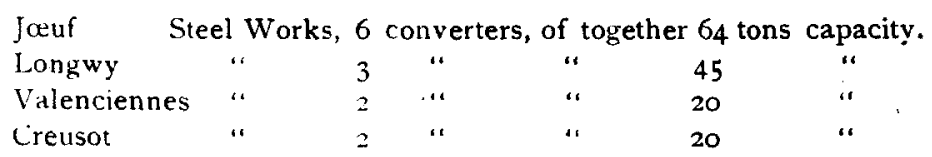

Adding the works in course of erection, Pagny-on-theMeuse Steel Works, two converters, of together twenty tons capacity, the sum total is fifteen converters with an aggregate capacity of 169 tons. equal to about $5,00,000$ tons of steel annually.

The three first steel works are specially converting Meurthe and Moselle pigs obtained from the local oölitic ores; the fourth (Creusot) converts pig iron made with its own oölitic Mazenay ores.

The Jœuf Works (Mešsrs. de Wendel) have not exhibited anything; the Creusot Works (Messrs. Schneider' \& Co.) have only exhibited their phosphoric mineral manures in the Agricultural Section.

The Longwy Steel Works make 250 to 300 tons of basic steel per day with their own pig (of which the composition is given above). They produce especially soft, very soft, and extra soft steels (Nos. 6, 7, 8 of the Longwy hardness scale), and also particularly extra soft steels (No. 9) for making wire, nails, etc. The breaking-stress for this lastnamed steel is less than 5,000 pounds per square inch, and the elongation is more than twenty eight per cent. Its composition is given as follows:

Per Cent.

Manganese, . . . . . . . . . . . 0225 to 0.30

Sulphur, . . . . . . . . . . . spur.

Phosphorus, . . . . . . . . . . . . . 003 to $0^{\circ} 05$

These works are delivering to the trade blooms, billets, bars of every description, plates and rails, as also wire rods.

The North and East Steel Works, at Valenciennes, are also using basic pigs of the Meurthe and Moselle district, mixed sometimes with extra-phosphorous pigs, imported from Germany or from the North of England. They give the 
possible output of their two converters as 80,000 to 100,000 tons of basic steel annually. They sell rails, girders, bars, billets and blooms, and their exhibits can be seen in the North of France special annex.

The Stenay Iron and Steel Works, in the Meuse Department, are about the only works in France working their process. They decarbonize pig iron so as to obtain rolled or cast products into small (one ton or about) converters, according to the Robert Patented Process. ${ }^{*}$ Their exhibit includes numerous specimens of the products." +

MANUFACTURE OF STEEL IN OPEN-HEARTH FURNACES.

According to Prof. Jordan's statements there were in 1877 fifty-one open-hearth furnaces in France. Their number appears to have decreased in 1887 , owing to the closing of the Sireuil Works, in which Messrs. Martin were the pioneers of this new manufacture. The official statistics furnish the following data for 1887 :

Number of open-hearth furnaces in work, . . . . . . . . 69

Output in 1887, . . . . . . . . . . . . . 1437764

viz: Rails, . . . . . . . . . . . . . . . . 13.709

Bars, . . . . . . . . . . . . . . 9 90,498

Plates and sheets, . . . . . . . . . 39,557

But the number of furnaces in working order in 1889 is notably greater, and may be estimated at about seventy-five furnaces of various systems and sizes.

Since the time of the introduction by Messrs. Martin of the new process in their Sireuil Works, the size of the openhearth furnace has always been increasing. Instead of the three to four-ton furnaces first used, ten-ton furnaces, twenty-ton furnaces, and even, as in some steel works of the Loire district, thirty-five ton furnaces can now be found.

In reference to the manner of constructing the furnace, the majority are of the fixed type, the so-called SiemensMartin furnace, designed at first by the Messrs. Martin themselves, and having regenerators situated underneath the

The Robert process will be specifically treated further on.

$\pitchfork$ foum. Iron and Steel Inst., No. 2, 1887, pp. 24-25. 
hearth, and the reversing valves on one of the small sides. In two or three steel works only can the Pernot furnaces be found, with a revolving circular basin or hollow hearth, or the Batho furnace, with a round hearth, supported by an iron plate, free underneath, and with round regenerators .with plate-iron casing placed laterally and above ground.

The mode of working is ustually the "scrap process." What is known as the "ore process" does not appear to be used in France. The continued use of scrap and ore known as the "Landore process," is used only at the Alleyard Works. Prof. Jordan states that the nature of the lining varies in the different works, and according to the description of materials used. Sometimes the lining is acid; that is, it is made with sand, gannister, or silicious puddle; sometimes it is basicthat is, made with magnesia bricks or puddle (according to the system patented in 1869 by Mr. Emile Muller), or with dolomitic bricks and blocks; at other times the lining is ncutral; that is, made with chrome ore (according to the Valton-Remaury process). When the lining is made with chrome ore, Messrs. Valton and Remaury state that no material is taken from the lining either by the molten metal or by the slag, so that no corrosion takes place, and it becomes possible to act on the metal either by scraps or by ores, or by various agents in such a manner as to effect a complete dephosphorization, and to produce various descriptions of steel. Messrs. Valton and Remaury exhibit drawings of furnaces neutrally lined, specimens of their chrome ore and linings, and products of some steel works working their process.

French steel works, such as Fourchambault and Alais, for instance, choose the neutral lining rather than the basic one, which, they say, is sooner worn out, and above all when some iron ore is used in the process.

The properly-called dephosphorizing mode of working; that is, the conversion of truly phosphoretic pigs (such as those of Meurthe and Moselle) in cast steel by the open-hearth process, is not yet much used in France. This description of pig iron is sooner dephosphorized in the basic Bessemer con verter. M. Fould-Dupont, however, shows in his beautiful 
exhibit (Central Gallery) cast steel of every form obtained in open-hearth furnaces from his Pompey pig iron.

On the other hand, in many steel works, the basic or neutral lining is used for making open-hearth steel with ordinary pig and scrap, not free enough from phosphorus to yield good steel on an acid lining, and too low in phosphorus to be worked in the basic converter. Some of them are even working pure pig and scrap upon basic and neutral hearths, and produce soft and extra soft steels of very high quality ; these steels being, besides, either simply carbon steels, or steels into whose composition enter silicon, manganese, and chrome, inasmuch as the open-hearth furnace is a very convenient and adaptable one, which allows the easy introduction and stirring of any reagent in the metallic bath.

[To be continued.]

MEMOIR OF FREDERIC GRAFF.

Frederic GrafF, Civil Engineer, whose sudden death upon the 3oth of March, 1890, his fellow-members have to mourn, was the son of Frederic Graff and Judith Swyer, his wife, and was born in Philadelphia, March 21, 1817.

His great-grandfather, Jaco Graff, came to this country from Hildesheim, Germany, in 1741 , and established a brickyard in Philadelphia, where he conducted a large business. His son, Jacob Graff, Jr., was a builder, and owned the house in Market Street, above Seventh, where Mr. Jefferson wrote the Declaration of Independence.

Jacob Graff, Jr., left two sons, Charles and Frederic, who were well known to many of us. Frederic, Sr., was born in 1774, in the house above-mentioned. In 1779 , he was engaged as draughtsman and assisting engineer in erecting the city water works, in Centre Square, of which he was appointed Superintendent, in 1805 , continuing in that position as long as they were used. These works were begun in May, I799. They were started January I, I80 I, and were used until September 5,1815 , and were finally taken down in 1827 . 